\title{
An Analysis on the Competitiveness of the Oil Refinery Market in South Korea*
}

\author{
Heedae PARK
}

Received: March 13, 2020. Revised: April 11, 2020. Accepted: May 05, 2020

\begin{abstract}
This study analyzes the degree of competition in the oil refinery market in Korea, which is considered an oligopoly market. The price of gasoline and diesel and the quantity of supply are used to identify the market competition. We also analyze whether the oil tax reduction policy has affected market competition. The competitiveness of the market was examined using monthly data from 2008 to 2019 . BresnahanLau method was employed to estimate the degree of competition in the oil refinery market, which is frequently used in the industrial studies. The analysis shows that the gasoline and diesel markets seem close to a perfect competitive market. Also, the tax cut has weakened market competition. In other words, the monopolistic power has increased in the market, so consumers have not benefit from the price cuts as much as tax cuts. Although the oil refinery market where four major companies are competing, the government's monitoring and price disclosure system help the market to be highly competitive as much as a perfect competition market. The tax cut, in the high oil price era, has a negative effect on the competition because of an information asymmetry about the price-setting process between suppliers and consumers.
\end{abstract}

Keywords:Competition, Oil Industry, Gasoline, Diesel, Bresnahan-Lau Method

JEL Classification Code: C30, D4, L10, Q41

\section{Introduction}

Petroleum is vital to both our daily life and the industrial production. Of course, thanks to technological developments, many alternative energies such as solar, electric energy, hydrogen, etc., have been developed, and the alternative energy market has grown. However, the alternative energy still has many drawbacks, so there are remaining steps to actual use in our life. As of 2019, Korea's oil consumption ranks 8 th in the world. However, most of oil consumption in South Korea depends on imports. South Korea is ranked as the world's fifth-largest importing country in 2019. Therefore, market events in the world petroleum market can have huge impact on the Korean economy as a whole.

Recent geopolitical risks affecting international oil prices, such as reduced demand from the spread of the COVID-19

*This paper was extracted and developed from the Master's thesis. 1First Author and Corresponding Author. Associate Research Fellow, Korea Maritime Institute, Korea. Email: heedae85@kmi.re.kr

(c) Copyright: The Author(s)

This is an Open Access article distributed under the terms of the Creative Commons Attribution Non-Commercial License (http://Creativecommons.org/licenses/by-nc/4.0/) which permits unrestricted noncommercial use, distribution, and reproduction in any medium, provided the original work is properly cited. virus and thebreakdown of oil production negotiations between Russia and OPEC + , have had a major impact on international and domestic economic indicators. As mentioned above, the domestic oil refinery industry, which has high external dependence, can be greatly influenced by these external factors, which also can affect the market where consumers purchase the petroleum-processed products through changes in supply and price.

The oil refinery industry is defined as a business which refines petroleum and sells petroleum-processed products. The domestic refinery industry is considered a typical oligopoly market where only four refiners (SK Energy, GS Caltex, Hyundai Oil Bank, S-Oil) and government-managed gas stations participate in the competition. The Korea Fair Trade Commission define companies as dominant market players if the top 1 company's market share (Concentration Ratio 1, CR1) is over 50\%, or the sum of the top 3 companies' market shares (Concentration Ratio 3, CR3) are over 75\%. In 2019, CR3 in the domestic oil refinery market was estimated about $70 \%$ to $78 \%$. It varies depending on the measure of market share.

In this oligopolistic structure, firms often choose to collude rather than compete in the market to avoid aggressive competition. In other words, the dominant 
firm tends to be a complete monopoly firm by leading the prices and exercising monopolistic power when selling the products. This can be seen in the collusion cases caught by the Fair Trade Commission. Since oil refiners were fined for collusion to allocate their market shares in advance in 1988, they were continuously caught and fined for price collusion in the bidding market for military supply in 1998, 2001 and 2003. Later, they tried to fix the price of light crude oil such as gasoline and diesel in 2017, and also fix the price of liquefied petroleum gas (LPG) in 2010. All the cases mentioned were caught by the FTC and the participants in the collusion were fined.

As such, the domestic oil refinery market can be seen as an oligopolistic market in terms of the number of market participants, and it is frequently considered to have a market environment that is close to the monopoly market because participating companies frequently collude. So, in general, there are many views that domestic oil refinery market is a monopolistic market. However, it is necessary to analyze whether these oil refinery companies have enough monopoly power in the petroleum products market to harm consumers. The antitrust law is intended to help consumers to purchase products in a fair market and to allow market participants to enter and exit freely. However, it is difficult for new market participants to enter the market freely since the oil refining requires initial facilities and excessive initial investment. Because of this, antitrust laws in the oil refining industry may be more effective as a policy to protect consumers. In this situation, it can be more appropriate to measure the degree of competition by analyzing whether the oil refinery companies exercise monopoly power over consumers than just using the number of participating companies or concentration of market share in the oil refinery industry. With this in mind, the main purpose of this study is to analyze the degree of competition in the oil refining industry, which can have a great influence on the national economy as a whole. In other words, this paper empirically analyzes whether the oil refinery market in Korea is oligopolistic market as normally considered.

According to the traditional monopoly power hypothesis, if dominant firms exist in the market, these firms determine the output and the price at levels that maximize their profits. As a result, the market does not meet the desired output, so the social welfare in the market is inevitably reduced. The logic of this hypothesis was derived from the StructureConduct-Performance model (S-C-P model) presented by Mason (1939) and Bain (1951). According to the S-C-P model, the market share represented by the HHI or CR ratio is inversely proportional to the competitiveness of the industry. However, this analysis is meaningless when the industrial structure is strongly regulated by exogenous factors such as governmental control. To overcome the limitations of this structural approach, a new empirical industrial organization
(NEIO) methods have developed. The Panzar-Rosse model and the Bresnahan-Lau model are the representative models. These models analyze the industry's form of competition by estimating individual firms' simplified import function or aggregate supply and demand functions. This study aims to analyze the competitiveness of the oil refinery industry mainly using the Bresnahan-Lau model. This study first estimates the demand and supply functions of the gasoline and diesel markets. Then, the market competitiveness was derived through the estimated demand and supply functions in each market. Additionally, this study investigates the policy effects of tax cuts in the oil refinery market by analyzing the changes in market competitiveness caused by the policy.

\section{Literature Review}

There has been much research which studied the oil refinery industry in a variety of topics and methodologies. For example, Bettendorf et al. (2003) studied the price asymmetry of the Dutch gasoline market. The paper used weekly price data from 1996 to 2001 and analyzed using an asymmetric error correction model. The estimation results showed that price asymmetry has a negative impact on consumer welfare. Many previous studies have focused on the competition in the oil refinery markets and the effectiveness of the government support policies. Kim (2018) analyzed the price competition in the domestic gas station market using the Spatial Durbin Panel model. The subject of analysis was gasoline. Daily gas station price data for the year of 2010 was used for analysis. The results showed that the average rents in region where the gas stations located in and the prices played an important role in determining the market price. Hastings (2004) also analyzed price changes at gas stations in San Diego, USA, using the difference in differences model. Switching to a well-known brand gas station, the price of the gas station rose by about 5 cents. In addition, the effects of fluctuations in the international oil prices on the domestic market (Kim, 2013) and the effects of government support policies (Son, 2013; Lee \& Kim, 2015; Choi \& Suh, 2017; Kim \& Kang, 2019; Kwon et al., 2019; Yun et al., 2019; Gwon, 2020) have been investigated.

The Bresnahan-Lau model has been widely used to analyze market competition in various industries. There are various studies analyzing the competitiveness of the financial and manufacturing markets using the BresnahanLau model used in this paper. Shaffer (1989) used the time series data from 1941 to 1983 to analyze competition in the US banking industry. The paper contradicted the hypothesis that the increase in concentration had reduced competition among banks and encouraged collusion as claimed in the previous studies. It was also found that there was no evidence that market-dominant banks set noncompetitive prices, such 
as raising loan rates. Thus, even though a concentrationprofitability relationship was found, this was not a monopoly, but a result of the bank's increased management efficiency. Moreover, Zardkoohi and Fraser (1998) analyzed the US banking market by state. The analysis period was 29 years from 1964 to 1993 . The results showed that most states had highly competitive banking markets. In particular, the US has experienced the fierce competition in the banking industry, and state deregulation policy did not affect the degree of competition in the banking industry. Toolsema (2002) also used the Bresnahan-Lau model to analyze the competition in the Dutch consumer financial market. Directly considering the imperfections of the credit market, it differentiates itself from previous research. The analysis of the consumer credit market showed that the Dutch financial market was close to perfect competition. This study differed from the previous studies about the banking industry in other European countries, which claimed that there is monopolistic competition or collusion in the banking sector. Gruben and Mccomb (2003) analyzed the monthly data of the Mexican banking industry from 1987 to 1993, and found that the financial liberalization such as privatization and the signing of the North American Free Trade Agreement (NAFTA) resulted in hypercompetitive behavior in the banking industry.
Frode (2004) conducted an empirical study focusing on bottlenecks in the Norwegian electricity market. On the demand side, they found inelasticity in the long run and the electricity market would become competitive in the long run. However, in the bottleneck period firms generated profits in the short term. Thus, on the day or time of the bottleneck, the suppliers were shown to have partial market dominance. In the long run, however, market dominance did not exist.

This study differs from previous studies in that it grasped the current situation by using the latest data of the oil refinery market in Korea that had been recently collected. It is also meaningful in that we considered the exogenous factors such as geopolitical risks to fully control the other channel to affect the market condition. In addition, this research examines the effectiveness of government policies such as oil tax reduction in terms of improving competitive market condition. Thus, this study brings a more accurate and precise analysis of the market competitiveness of the Korean oil refinery industry, which was normally regarded as an oligopoly market.

\section{Data}

The major subjects of the analysis are gasoline and diesel, among various petroleum products. Since gasoline

Table 1: Descriptive Statistics

\begin{tabular}{|c|c|c|c|c|}
\hline Variables & Mean & SD & Min & Max \\
\hline Price of Gasoline (\$) & 1.68 & 0.21 & 1.33 & 2.06 \\
\hline Price of Diesel (\$) & 1.49 & 0.21 & 1.10 & 1.92 \\
\hline Consumption of Gasoline (Bbl) & $6,123.3$ & 642.3 & 4,719 & 8,605 \\
\hline Consumption of Diesel (Bbl) & $12,399.9$ & $1,546.8$ & 9,245 & 16,487 \\
\hline Output of Gasoline (Bbl) & $11,438.8$ & $2,193.5$ & 6,166 & 15,864 \\
\hline Output of Diesel (Bbl) & $25,955.8$ & $3,303.6$ & 18,370 & 32,770 \\
\hline Industrial Product Index $(2015=100)$ & 97.1 & 9.3 & 63 & 108.4 \\
\hline Consumer Price Index (public transportation) $(2015=100)$ & 95.2 & 7.9 & 81 & 112.2 \\
\hline Dubai crude oil Price $(\$ / B b l)$ & 77.6 & 25.7 & 26.9 & 131.3 \\
\hline Average Monthly Wage (\$) & $3,410.16$ & 617.05 & $2,327.97$ & $5,433.85$ \\
\hline Interest rate of company loan & 4.74 & 1.17 & 3.28 & 7.8 \\
\hline $\begin{array}{l}\text { GPR index (Saudi Arabia) } \\
\text { (average of } 2000 \sim 2009=100 \text { ) }\end{array}$ & 103.9 & 27.7 & 44.7 & 196.3 \\
\hline $\begin{array}{l}\text { GPR index (South Korea) } \\
\text { (average of } 2000 \sim 2009=100 \text { ) }\end{array}$ & 117.6 & 44.2 & 51.1 & 274.4 \\
\hline $\begin{array}{l}\text { * SD stands for Standard Deviation } \\
{ }^{* *} \text { Prices and wages were converted into dollars at a conversion } \\
\text { rate of }(1,000 \text { won }=\$ 1)\end{array}$ & & & & \\
\hline
\end{tabular}




\section{GPR Benchmark Index (GPR)}

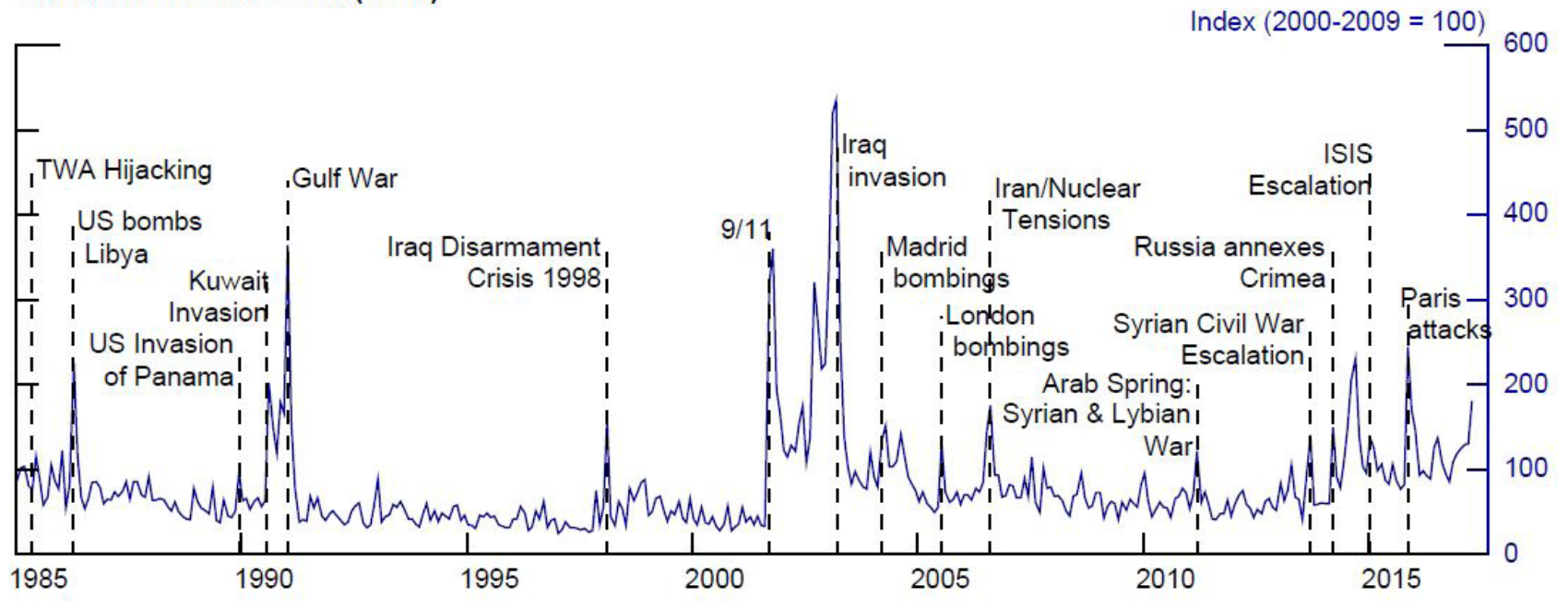

Source: Economic Policy Uncertainty

*TWA stands for Trans World Airlines

Figure 1: GPR (Geopolitical Risk) Benchmark index

and diesel are most commonly used by consumers in the domestic petroleum products, this paper focuses on these two products to analyze the oil refinery market. High-quality gasoline and kerosene are also traded by consumers, but trading volume of high-quality gasoline are relatively small compared to that of normal gasoline. Kerosene is mostly consumed only in winter. So, this paper only focuses on gasoline and diesel market. The data were obtained from the Korea National Oil Corporation's oil information network, the Bank of Korea's economic statistics system, the OPNET, the Financial Supervisory Service's disclosure system, and the National Statistical Office. The summary statistics for the data are presented in Table 1.

The time series data used for the analysis was collected monthly and the sample period is from January 2008 to October 2019. Therefore, 142 observations in total were utilized for the analysis. This paper analyzed the latest data which is recently available to investigate the degree of competition in the oil refinery market in recent years and to update the empirical estimation results that previous studies has suggested. Thanks to the latest dataset, we could analyze the effects of tax reform, which was implemented in November 2018 . The oil tax was reduced by $15 \%$ for about six months, which means the tax suppliers adds to an oil price was lower during the period from November 2018 to May 2019. This policy was extended once and maintained until August 2019, but the rate of reduction decreased from $15 \%$ to $7 \%$.
In order to analyze the competition in the oil refinery market, it is necessary to estimate the demand and supply functions for gasoline and diesel. To estimate the demand function, we use aggregate consumption as dependent variable. We add other variables affecting demand, such as gasoline and diesel are gas station sales price, income, and price of substitute goods to the demand function. The price is the monthly mean after-tax price averaged over all gas stations in the market. We also add macroeconomic factors to the demand function. Although Gross Domestic Product (GDP) is commonly used as a proxy variable for macroeconomic condition and national income, the seasonally adjusted industrial production index was used in this research due to the absence of monthly data of GDP. To meet the identification condition of the demand function, we used composed price index of several types of public transportation as an exogenous variable. The index merely affects demand but not marginal cost, so it plays an important role in identifying the demand function. The public transportation price index was calculated by averaging price index of each type of public transportation such as taxi, city bus, intercity bus, and the express bus.

To estimate the supply function, we use monthly aggregate level of oil production as dependent variable, which was provided from the Korea National Oil Corporation. We also use international crude oil price, wage, interest rates, and geopolitical risk index as variables affecting the supply. 
The international crude oil price used in this paper is the price of Dubai crude oil because the Dubai crude oil accounts for most of the total oil imports in Korea and it was imported through long-term contracts. For wages, a representative input factor of production, the average wage for manufacturing companies with five or more employees was used. The additional important factor of production is capital. The interest rate was used as a proxy variable for cost of capital. An interest rate on newly issued company loans at the time of data was used. In addition, we use geopolitical risk index (GPR) developed by the US Federal Reserve Board and provided from the Economic Policy Uncertainty. The GPR index reflects the uncertainty and anxiety spread in the world based on the frequency of words related to geopolitical tensions in major international newspapers, tax reports from the Congress Budget Office, and prospective surveys conducted by the Federal Reserve Bank of Philadelphia. In this paper, the index is used as a proxy variable for the degree of geopolitical risk affecting the oil market. Figure 1 depicts the GPR Benchmark index from 1985 to 2015 with major geopolitical events marked. In this paper, we use two countries' geopolitical risk indexes, namely Saudi Arabia and South Korea. Saudi Arabia is one of the major oil supplier country, so the geopolitical risks in Saudi Arabia are expected to affect the international oil market and the worldwide oil supply. South Korea's geopolitical risk index is used to consider domestic uncertainties.

\section{Methodology}

\subsection{Theoretical Model}

According to the microeconomic theory, if a market is a perfect competition market, the equilibrium price of the market will be equal to the marginal cost. However, if a market is a monopoly market,profit-maximizing firms will choose quantities such that marginal cost equals marginal revenue, the market price will be usually determined above the marginal cost. Therefore, the degree of competition in the market can be measured by the difference between the marginal cost and the equilibrium price. The BresnahanLau (B-L) model proposed a method to analyze the degree of competition within a given market using simultaneous equations consisting of the supply and the demand function. The B-L method can be analyzed, not with the data of individual companies, but with the entire industry data. Assume that there are $\mathrm{N}$ symmetric companies. The profit function of an individual company is given by the Eq. (4.1).

$$
\pi_{i}=p \cdot q_{i}-c_{i}\left(q_{i}, z_{S}\right)-F C_{i}
$$

$\pi_{i}$ is profit, $q_{i}$ is quantity, $p$ is price, $c_{i}$ is cost, $z_{S}$ is an exogenous variable that affects the marginal cost of an individual company but does not affect demand, and $F C_{i}$ is the firm's fixed cost.

The individual inverse demand function is given by the Eq. (4.2)

$$
p=f\left(Q, z_{D}\right)=f\left(q_{1}+q_{2}+\cdots+q_{n}, z_{D}\right)
$$

$z_{D}$ is an exogenous variable that affects demand but not the marginal cost. The first order condition of profit maximization of an individual company is given by the Eq. (4.3).

$$
\frac{d \pi_{i}}{d q_{i}}=p+f^{\prime}\left(Q, z_{D}\right) \frac{d Q}{d q_{i}} \cdot q_{i}-c_{i}^{\prime}\left(q_{i}, z_{S}\right)=0
$$

The sum of the individual company conditions is given by the Eq. (4.4).

$$
p+f^{\prime}\left(Q, z_{D}\right) \frac{d Q}{d q_{i}} \cdot \frac{1}{n} Q-c_{i}^{\prime}\left(q_{i}, z_{S}\right)=0
$$

Summarizing Eq. (4.4),

$$
\begin{aligned}
& p=-\lambda f^{\prime}\left(Q, z_{D}\right) \cdot Q+c_{i}^{\prime}\left(q_{i}, z_{S}\right) \\
& \lambda \equiv \frac{d Q}{d q_{i}} \cdot \frac{1}{n}=\left(1+\frac{d \sum_{i \neq j} q_{j}}{d q_{i}}\right) \cdot \frac{1}{n}
\end{aligned}
$$

$\lambda$ is a function of the average firm's conjectural variation. In a perfect competition market, $\lambda=0$. In a perfect competition market, price is an exogenous variable and Every participant is a price taker. Thus, Increasing the output of one firm reduces the output of another firm. The magnitude of the reduced output is equal to that of the increased output. In the Cournot model, all firms determine output at the same time and do not take into account other firm's output. Thus, $\lambda=1 / \mathrm{n}$. In monopoly or perfect collusion, an increase in the output of one firm make the output of all other firms increase in the market. Therefore, $\lambda$ becomes 1 .

$$
\lambda \equiv \frac{d Q}{d q_{i}} \cdot \frac{1}{n}=\left(1+\frac{d \sum_{i \neq j} q_{j}}{d q_{i}}\right) \cdot \frac{1}{n}
$$

The market structure according to the value of $\lambda$ is shown in Table 2.

\subsection{Empirical Model}

We apply the B-L model to test the degree of competition the refinery market. In the B-L model, competition is measured through simultaneous equations of supply and demand functions. The first equation is demand function, and the second is supply function derived from the company's 
Table 2: Market structure according to $\lambda$

\begin{tabular}{|l|l|}
\hline & \multicolumn{1}{|c|}{ Market structure } \\
\hline$\lambda=0$ & Perfect Competition \\
\hline $0<\lambda<1$ & Monopolistic Competition \\
\hline$\lambda=1$ & Monopoly orCollusive Oligopoly \\
\hline$\lambda=1 / n$ & Symmetric Cournot Oligopoly. \\
\hline
\end{tabular}

profit maximization conditions. One of the coefficients of the supply function can be thought of as the firm's response to the change in the output. The demand function is shown in the Eq. (4.5).

$$
\begin{aligned}
& Q_{D}=\alpha_{0}+\alpha_{1} P+\alpha_{2} Y+\alpha_{3} Z+\alpha_{4} P \cdot Z \\
& +\alpha_{5} \text { Quarter }+\varepsilon
\end{aligned}
$$

QD is consumption, $\mathrm{P}$ is the price of gasoline and diesel, $\mathrm{Y}$ is an exogenous variable that takes into account income and economic situations, and $\mathrm{Z}$ is a factor that does not give influence but affects the limited consumption influence at a competitive cost. Quarter dummy were added to control the seasonality of demand. The demand function Eq. (4.5) can be summarized as shown in the Eq. (4.6).

$$
P=\frac{1}{\alpha_{1}+\alpha_{4} Z}\left(Q_{D}-\alpha_{0}-\alpha_{2} Y-\alpha_{3} Z-\alpha_{5} \text { Quarter }-\varepsilon\right)
$$

The total revenue function is derived by multiplying the quantity of total supply by the Eq. (4.6). The marginal revenue is the derivative of total revenue function with respect quantity. Marginal revenue is given by the Eq. (4.7).

$$
M R_{i}=\frac{d T R}{d q_{i}}=P+\frac{\lambda n}{\alpha_{1}+\alpha_{4} Z} \cdot q_{i}, \lambda \equiv \frac{d Q}{d q_{i}} \cdot \frac{1}{n}
$$

The firm's marginal cost function is shown in the Eq. (4.8).

$$
M C_{i}=\beta_{0}+\beta_{1} Q+\beta_{2} P_{o i l}+\sum_{j=2}^{6} \beta_{j+1} E X V+\mu_{i}
$$

Various variables were considered to affect supply function. $P_{o i l}$ is the oil price. Usually, refinery companies in South Korea have purchased Dubai crude oil. So the price is Dubai crude oil which accounts for the majority of domestic import. Because the price of crude oil accounts for most of the cost of production, it has to be considered production function.There are five control variables in EXV. This includes wages and interest rates, the most basic components of supply function. In addition, geopolitical risks were also added. Crude oil is produced only in a few countries. In particular, Dubai crude oil should also be considered as price fluctuations are very large depending on the political situation in the Middle East. In addition, the domestic situation needs to be considered. As South Korea is a divided nation, there are always risks.Finally, we added quarter dummy variables to control seasonality.

The market equilibrium condition where marginal revenue and marginal cost coincide is given by the Eq. (4.9).

$$
\begin{aligned}
& P+\frac{\lambda n}{\alpha_{1}+\alpha_{4} Z} \cdot q_{i}=\beta_{0}+\beta_{1} Q+\beta_{2} P_{o i l} \\
& +\sum_{j=2}^{6} \beta_{j+1} E X V+\mu_{i}
\end{aligned}
$$

Taking the average to measure the degree of competition, the supply function of the refinery market can be derived from the Eq. (4.10).

$$
\begin{aligned}
& P=-\lambda\left[\frac{n}{\alpha_{1}+\alpha_{4} Z} \cdot q_{i}\right]+\beta_{0}+\beta_{1} Q+\beta_{2} P_{\text {oil }} \\
& P=-\lambda\left[\frac{n}{\alpha_{1}+\alpha_{4} Z} \cdot q_{i}\right]+\beta_{0}+\beta_{1} Q+\beta_{2} P_{\text {oil }} \\
& +\sum_{j=2}^{6} \beta_{j+1} E X V+\mu
\end{aligned}
$$

By estimating the supply function in Eq. (4.10) using the values estimated from the demand function in the Eq. (4.5), we can estimate the degree of competition of the oil refinery market through $\lambda$. However, according to Bresnahan (1982) and Lau (1982), even if both the demand function and the supply function are identified, the demand function has to include an interaction term between at least one of endogenous price variables and exogenous variables. Thus, $\lambda$ is identified. That is, the condition that $0, \alpha_{4} \neq 0$ must be satisfied. We used STATA 16 (MP) for estimation.

\section{Estimation Results}

\subsection{Gasoline}

The degree of competition in the gasoline market was estimated using the B-L model. The model (1) of Table 3 represents the estimation results of the aggregate demand function and aggregate supply function for Gasoline market.

From the estimation result of the demand function, which is represented in Panel A section in the model (1), the result is consistent with the law of demand that the demand decreases when the price rises. However, the slope of the aggregate demand function is determined as $\partial Q_{D} / \partial p$. In 
other words, the size of $\alpha_{1}+\alpha_{4} Z$ from the Eq. (4.6) is the empirically estimated slope of the demand function. Since the coefficient of gasoline price $\left(\alpha_{1}\right)$ is larger than the coefficient of interaction term $\left(\alpha_{4}\right)$ multiplied by the interaction term itself $(Z)$, the estimated demand function is downward sloping as the demand law. The coefficient of industrial production index, which is used as a proxy variable for national income and macroeconomic condition, positively affects the demand and was estimated statistically significant. If the economy is growing, gasoline consumption would also increase. The most consumption of gasoline made at gas stations is for driving own cars. Therefore, if gasoline prices rise, the consumer who drives their own cars otherwise, would use public transportation, which is relatively cheaper. Thus, public transportation can be an alternative to gasoline consumption. In this way, the public transportation price index, which is a price index of substitutes for gasoline, has a negative impact on the gasoline demand. The coefficient of the price of substitutes was negative but not statistically significant. In the theoretical framework, the effects of substitute should be positive, but the stylized fact was hardly proven empirically because there still are many factors that are not explained simply by relative price. In addition, we can find that that the identification conditions of the B-L model are satisfied in the sense that the coefficient of the interaction term was statistically significantly different from form 0 .

The aggregate supply function was estimated using the estimated coefficients from the demand function. The estimation results are presented in Panel B section of the model (1) in Table 3. The coefficient representing the degree of competition in the gasoline market, which is the main concern of this study, was estimated to be about 0.015 and statistically significant. According to the B-L model, if the coefficient for competition is estimated at 0 , the market is considered as a perfectly competitive market, and if it is 1 , it is considered as a monopoly market. Given that the gasoline market sold is about 0.015 , it is inferred that the gasoline market in South Korea is close to a perfect competitive market. The coefficient of the gasoline production is positive, but the impact on the market seems negligible. The effects of some variables related to the cost such as crude oil import price and geopolitical risk indexes were estimated positive. That means if the oil refinery firms are affected from the exogenous cost shock, the selling price rises in the domestic market. However, the cost of labor and capital did not significantly affect the price. In general, labor and capital considered in the production function seem to have a minor impact on the oil refinery market. The characteristics of the oil refinery market contributes to the reason of minor impact of the input factors. Since the capital investment was highly concentrated at the early stage of the business, there is no great demand for capital when the business settled. It is also a result of reflecting the situation that there is no need for labor force due to the recent technological progress of the refinery industry. The geopolitical risks in Saudi Arabia showed significant effect on domestic supply function, whereas the geopolitical risk in Korea did not show any significant effect.

\subsection{Diesel}

The model (2) of Table 3 represents the estimation results of the aggregate demand function and aggregate supply function for Diesel market. Like the gasoline market, the $\mathrm{B}-\mathrm{L}$ model is used to measure the competition in the diesel market. The estimation results show consistent pattern with the estimation results of gasoline market. The results of estimating the aggregate demand function of diesel was presented in Panel A section in the model (2). The diesel price has a negative value and is estimated significantly. Therefore, we can see that in the domestic diesel market the estimation result is in line with the law of demand, where the price rises and the demand decreases. The slope of the aggregate demand function of diesel is also downward sloping as that of gasoline. The industrial production index, a proxy variable representing income and overall economic conditions, was positive and statistically significant. The industrial production index represents the industrial demand in the diesel market as a large part of consumption of diesel takes place in the industrial sectors. As with gasoline, price of substitutes dose not significantly affect the demand of diesel.

The aggregate supply function in Panel B section shows that the competition in the diesel market, which is the main result of this study, was estimated to be about 0.025 , which is statistically significant. According to the B-L model, the degree of monopoly power in the domestic diesel market is very close to zero. Similar to the gasoline market, the production level of diesel is positively correlated with the price. In addition, the factors which can affect production cost such as crude oil import price and geopolitical risks show positive correlation to the price. Wage does not show significant impact on supply in the diesel market as in the gasoline market. However, interest rates representing the cost of capital factor show positive impact on the price. As with gasoline, geopolitical risks in Saudi Arabia affect supply the prices in the domestic market, but domestic geopolitical risks do not.

\subsection{The Effects of Tax reform on the Oil Refinery Market}

Gasoline and diesel have a significant impact on our daily life. As a result, the government is very interested in the supply and demand in the oil refinery market. Therefore, many types of taxes are imposed on the price of gasoline and diesel. Except for Germany and the United Kingdom, few countries impose more taxes than South Korea. Currently, the oil tax in South Korea is lump-sum tax. Specifically, the 
lump-sum oil tax includes sub-taxes such as transportation tax, energy tax, environment tax, driving tax, and education tax Transportation, energy and environmental taxes are firstly charged at KRW529 for gasoline and KRW375 for diesel. Then, the education tax is charged at $15 \%$ of the lump-sum part of the tax, which is the sum of taxes for transportation, energy and environment, and the driving tax is charged at $26 \%$ of the lump-sum tax. Usually, about $60 \%$ of the selling price after tax belongs to the government's tax revenue. This tax share is very high compared to other countries. Due to pressure on tax cuts and rising prices of gasoline and diesel in the market, the government has decided to reduce the taxes on gasoline, diesel and LPG by $15 \%$ from November 6 , 2018. As oil prices continued to remain high, the government extended it once in April 2019. From May 7, 2019, the tax cut was lowered from $15 \%$ to $7 \%$ and then the tax cut period was ended on August 2019.

The purpose of this section is to measure the changes in competition in the oil refinery market as a result of reduction in oil taxes. The announcement to cut the oil tax can be considered as an exogenous impact on the oil refinery market. When the tax is reduced and the price is expected to be adjusted, therefore the benefits of the tax cut are expected to be shared between suppliers and consumers. If the market is close to a perfectly competitive market, it is very likely that the price will immediately fall due to tax cuts. However, if the market is close to the monopolistic market, the price will not be very different from the price before the tax cut, and most of the benefits will be taken by the supplier.

Table 3: Estimation results of the Demand and Supply Functions

\begin{tabular}{|c|c|c|c|c|c|c|c|c|}
\hline \multirow{2}{*}{ Section } & \multicolumn{4}{|c|}{ (1) Gasoline } & \multicolumn{4}{|c|}{ (2) Diesel } \\
\hline & Variable & Coefficient & SE & P-value & Variable & Coefficient & SE & P-value \\
\hline \multirow{7}{*}{$\begin{array}{l}\text { Panel A: } \\
\text { Demand } \\
\text { Function }\end{array}$} & Price & $-2.591^{* * *}$ & 0.882 & {$[0.004]$} & Price & $-7.198^{* * *}$ & 1.394 & {$[0.000]$} \\
\hline & $\begin{array}{l}\text { Productivity } \\
\text { Index }\end{array}$ & $19.840^{* * *}$ & 7.271 & {$[0.007]$} & $\begin{array}{l}\text { Industrial } \\
\text { Production } \\
\text { Index }\end{array}$ & $29.739^{\star}$ & 16.356 & {$[0.071]$} \\
\hline & $\begin{array}{l}\text { Price index of } \\
\text { substitutes }\end{array}$ & -0.186 & 16.727 & [0.991] & $\begin{array}{l}\text { Price index } \\
\text { of substitutes }\end{array}$ & -7.174 & 28.957 & {$[0.805]$} \\
\hline & $\begin{array}{l}\text { Interaction } \\
\text { terms }\end{array}$ & $0.020^{*}$ & 0.011 & {$[0.062]$} & $\begin{array}{l}\text { Interaction } \\
\text { terms }\end{array}$ & $0.048^{* * *}$ & 0.018 & {$[0.008]$} \\
\hline & Constant & $5,083.331^{* * *}$ & $+1,793.2$ & {$[0.005]$} & Constant & $13,686.154^{* * *}$ & $3,079.715$ & {$[0.000]$} \\
\hline & Observations & \multicolumn{3}{|c|}{142} & Observations & \multicolumn{3}{|c|}{142} \\
\hline & R-squared & \multicolumn{3}{|c|}{0.700} & R-squared & \multicolumn{3}{|c|}{0.709} \\
\hline \multirow{10}{*}{$\begin{array}{l}\text { Panel B: } \\
\text { Supply } \\
\text { Function }\end{array}$} & Competition & $0.015^{\star * *}$ & 0.003 & {$[0.000]$} & Competition & $0.025^{\star * *}$ & 0.007 & {$[0.001]$} \\
\hline & \begin{tabular}{|l|} 
Production \\
\end{tabular} & $0.012^{* *}$ & 0.005 & {$[0.030]$} & Production & $0.015^{* * *}$ & 0.004 & {$[0.001]$} \\
\hline & $\begin{array}{l}\text { Crude oil } \\
\text { import prices }\end{array}$ & $7.200^{* * *}$ & 0.275 & {$[0.000]$} & $\begin{array}{c}\text { Crude oil } \\
\text { import prices }\end{array}$ & $7.168^{* * *}$ & 0.216 & {$[0.000]$} \\
\hline & Wage & $-0.000^{* *}$ & 0.000 & {$[0.016]$} & Wage & -0.000 & 0.000 & [0.694] \\
\hline & Interest rate & -20.168 & 12.285 & {$[0.103]$} & Interest rate & $25.397^{* *}$ & 9.918 & {$[0.012]$} \\
\hline & $\begin{array}{l}\text { GPR Index } \\
\text { (Saudi Arabia) }\end{array}$ & $0.705^{* * *}$ & 0.210 & {$[0.001]$} & $\begin{array}{l}\text { GPR Index } \\
\text { (Saudi } \\
\text { Arabia) }\end{array}$ & $0.521^{* * *}$ & 0.166 & {$[0.002]$} \\
\hline & $\begin{array}{l}\text { GPR Index } \\
\text { (Korea) }\end{array}$ & 0.120 & 0.132 & {$[0.366]$} & $\begin{array}{l}\text { GPR Index } \\
\text { (Korea) }\end{array}$ & 0.138 & 0.104 & {$[0.187]$} \\
\hline & Constant & $1,233.751^{* * *}$ & 120.903 & {$[0.000]$} & Constant & $690.077^{* * *}$ & 100.698 & {$[0.000]$} \\
\hline & Observations & \multicolumn{3}{|c|}{142} & Observations & \multicolumn{3}{|c|}{142} \\
\hline & R-squared & \multicolumn{3}{|c|}{0.914} & R-squared & \multicolumn{3}{|c|}{0.951} \\
\hline
\end{tabular}


Therefore, this research empirically investigates if the degree of competition in the domestic oil market has changed due to the oil tax reduction and figure out how the benefits of tax cuts were shared among market participants. To estimate the changes, we slightly adjust the supply function that we suggest above. We add the interaction term of the competition and a dummy variable indicating the tax cut period to the original supply function. The estimation equation is as shown in the following Eq. (5.1).

$$
\begin{aligned}
& P=-\lambda_{1}\left[\frac{n}{\alpha_{1}+\alpha_{4} Z} \cdot q_{i}\right]-\lambda_{2}\left[\frac{n}{\alpha_{1}+\alpha_{4} Z} \cdot q_{i}\right] \cdot D+\beta_{0}+ \\
& \beta_{1} Q+\beta_{2} P_{o} i l+\sum_{j=2}^{6} \beta_{j+1} E X V+\mu
\end{aligned}
$$

$\lambda_{1}$ stands for the degree of competition before the tax cuts and $\lambda_{1}+\lambda_{2}$ means the degree of competition during the tax cut period. Therefore, if $\lambda_{2}>0$, the tax cuts negatively affect the competition in the market. In other words, the tax cut weakened the competition and strengthen the monopolistic market power of the suppliers. Estimation results are presented in Table 5. In the case of gasoline in the model (1), before the tax cuts, the coefficient of competition variable seems to be close to 0 , which means a perfect competitive market. However, the market was less competitive during the tax cut period. The results were seen in the same way in the diesel market. Overall, it is concluded that the oil refinery companies, not consumers, benefited from the tax cuts.

\section{Discussion and Conclusions}

In this study, we used the New Empirical Industrial Organization Approach (NEIO) to analyze the degree of competition in the oil refinery market. In order to measure the degree of competition of the oil refinery market, the Bresnahan-Lau model is used in this study. Among the various oil refined products, only gasoline and diesel, which have the most influence on economic activity, were analyzed. This analysis shows that the gasoline and diesel markets are very competitive. Apparently, the oil refinerymarket has been supplied by only a small number of companies, but the degree of competition has been measured as close to perfect competition market.

The reasons for the intense competition in the oil refinerymarket can be various. With the Fair Trade Commission's rigorous monitoring, the oil refinery market has been gradually competitive. In addition, the government implemented various policies to control the monopolistic power in the market. For example, the government directly launched the government-sponsored gas station brand to compete with existing gas station brands. It started business in December 2011 and now has a share of about 10\%. Also the government introduced two platforms systems, namely, an e-commerce system, in which imported gasoline or diesel oil can be purchased online, and a petroleum mixed sales system, in which oils from various refiners can be sold at once. The government also tries to lower the information

Table 4: Estimation results of Tax reform effect on the

\begin{tabular}{|c|c|c|}
\hline \multirow{2}{*}{ Variable } & (1) & (2) \\
\hline & Gasoline & Diesel \\
\hline \multirow{3}{*}{ Competition } & $0.008^{*}$ & $0.023^{* *}$ \\
\hline & $(0.004)$ & $(0.009)$ \\
\hline & [0.072] & [0.011] \\
\hline \multirow{3}{*}{$\begin{array}{l}\text { Competition * Tax } \\
\text { cut }\end{array}$} & $0.004^{* *}$ & 0.001 \\
\hline & $(0.002)$ & $(0.003)$ \\
\hline & [0.033] & [0.698] \\
\hline \multirow{3}{*}{ Output } & $0.012^{* *}$ & $0.015^{\star * *}$ \\
\hline & $(0.005)$ & $(0.004)$ \\
\hline & [0.028] & {$[0.001]$} \\
\hline \multirow{3}{*}{$\begin{array}{l}\text { Dubai crude oil } \\
\text { Price }\end{array}$} & $7.178^{* * *}$ & $7.172^{* \star *}$ \\
\hline & $(0.271)$ & $(0.217)$ \\
\hline & {$[0.000]$} & {$[0.000]$} \\
\hline \multirow{3}{*}{ Wage } & $-0.000^{* *}$ & -0.000 \\
\hline & $(0.000)$ & $(0.000)$ \\
\hline & [0.025] & {$[0.726]$} \\
\hline \multirow{3}{*}{ Interest rate } & -7.359 & $27.025^{\star *}$ \\
\hline & (13.488) & (10.796) \\
\hline & [0.586] & [0.014] \\
\hline \multirow{3}{*}{$\begin{array}{l}\text { GPR(Saudi } \\
\text { Arabia) }\end{array}$} & $0.657^{* * *}$ & $0.514^{* * *}$ \\
\hline & $(0.208)$ & $(0.168)$ \\
\hline & [0.002] & [0.003] \\
\hline \multirow{3}{*}{ GPR(Korea) } & 0.088 & 0.130 \\
\hline & $(0.131)$ & $(0.106)$ \\
\hline & [0.504] & [0.221] \\
\hline \multirow{3}{*}{ Constant } & $1117.053^{* * *}$ & $671.613^{* * *}$ \\
\hline & $(130.898)$ & $(111.637)$ \\
\hline & {$[0.000]$} & {$[0.000]$} \\
\hline Observations & 142 & 142 \\
\hline R-squared & 0.917 & 0.951 \\
\hline \multicolumn{3}{|c|}{$\begin{array}{l}\text { Other control variables are not represented in the table. } \\
\text { Standard errors in parentheses } \\
\text { P-values in brackets } \\
\text { *** } p<0.01,{ }^{* \star} p<0.05,{ }^{*} p<0.1\end{array}$} \\
\hline
\end{tabular}
Supply function 
barriers that consumers face by introducing a mobile application showing real-time sales price of gasoline and diesel of all gas stations.

Improved refining capacity of the oil refinery company also contributes to the increased degree of competition. From 2000 to 2010 , each refiner invested heavily in the refining capacity. This led to oversupply in the domestic oil refinery market. Therefore, the constant oversupply in the market has reduced the market power of refinery companies.

In this paper, the degree of competition during the government's oil tax cut period was analyzed. The estimation results reveals that the degree of competition was weaker during the tax cut period. This is because that the gas stations usually stock up on several days' quantity sold, so they don't lower their prices until they sell stock. There is information asymmetry between gas stations and consumers. When the government decreased the tax, the suppliers can adjust their sales price for their sake. However, consumers do not know how the sales price is set. Therefore, even if the oil tax is lowered, it is not fully reflected in the consumer price.For example, there are some gas stations that decrease sales price as much as they save from the tax cuts, while others may not reflect the tax cut into the sales price. These various cases cannot be considered by consumers, so consumers should just accept the sales price that the suppliers set. Thus, the effect of tax cut policy was much less than the government expected.

Overall, the degree of competition in the Korean oil refinery market is estimated to be a near-perfect competition according to the estimation results in this paper. Considering government surveillance, the oil refinery market is almost considered an ideal market. However, there still has been a problem of information asymmetry between suppliers and consumers. Thus, it is necessary for the government to improve the public announcement system, so that consumers can always check the suppliers' actions and suppliers can hold each other in check.

In this study, more detailed information about single gas stations was not used. In future studies, it is necessary to analyze the degree of competition by adding data such as each gas station's location, price, and commercial area.

\section{References}

Appelbaum, E. (1982). The estimation of the degree of oligopoly power. Journal of Econometrics, 19(2-3), 287-299.

Bain, J. S. (1951). Relation of profit rate to industry concentration: American manufacturing. The Quarterly Journal of Economics, 65(3), 293-324.
Bettendorf, L., Van der Geest, S. A., \& Varkevisser, M. (2003). Price asymmetry in the Dutch retail gasoline market. Energy Economics, 25(6), 669-689.

Bresnahan, T. F. (1982). The Oligopoly Solution Concept Is Identified. Economics Letters, 10(1-2), 87-92.

Choi, D. R., \& Suh, G. H. (2017). A Study on the Effects of Small Business Management Result by the Korean Government: Focus on SEMAS. The Journal of Business, Economics, and Environmental Studies, 7(3), 33-43.

Frode, S. (2004). Do Bottlenecks generate market power? An Empirical Study of the Norwegian Electricity Market. Unpublished manuscript.

Gruben, W. C., \& McComb, R. P. (2003). Privatization, competition, and super competition in the Mexican commercial banking system. Journal of Banking \& Finance, 27(2), 229-249.

Gwon, J. H. (2020) Regulatory Disclosure of Large Business Groups in Korea. The Journal of Business, Economics, and Environmental Studies, 10(1), 45-50.

Hastings, J. S. (2004). Vertical relationships and competition in retail gasoline markets: Empirical evidence from contract changes in Southern California. American Economic Review, 94(1), 317-328.

Iwata, G. (1974). Measurement of Conjectural Variations in Oligopoly. Econometrica, 42(5), 947-966.

Kim, H. G. (2018). Price competition in Korean retail gasoline market: Focusing on spatial effects. Journal of Distribution Science, 16(4), 83-88.

Kim, S. (2013). A study on the impact of oil price volatility on Korean macroeconomic Activities: An EGARCH and VECM approach. Journal of Distribution Science, 11(10), 73-79.

Kim, S. G., \& Kang, M. J. (2019). A Study on the Influence of Regional Competency in Science and Technology Policy on Performance. International Journal of Industrial Distribution \& Business, 10(8), 55-65.

Kwon, W. T., Kwon, L. S., Yoo, H. G., \& Lee, W. S. (2019). Development of Cost-effective Mosquito Repellent and Distribution Method by Extracting Patchouli Oil. International Journal of Industrial Distribution \& Business, 10(12), 15-23.

Lau, L. J. (1982). On Identifying the Degree of Competitiveness from Industry Price and Output Data. Economics Letters, 10(1-2), 93-99.

Lee, K. H., \& Kim, Y. J. (2015). The Policy Effects on Traditional Retail Markets Supported by the Korean Government.Journal of Distribution Science, 13(11), 101-109.

Mason, E. S. (1939). Price and production policies of large-scale enterprise. The American economic review, 29(1), 61-74.

Panzar, J. C., \& Rosse, J. N. (1987). Testing for Monopoly Equilibrium, Journal of Industrial Economics, 35(1), 443-456. 
Shaffer, S. (1989). Competition in the U.S. Banking Industry, Economics Letters, 29(4), 321-323.

Son, S. H. (2015). A Study on the Cash Policies of Retail Firms,Journal of Distribution Science, 13(3), 69-77.

Toolsema, L. A. (2002). Competition in the Dutch consumer credit market. Journal of banking \& finance, 26(11), 2215-2229.
Yun, Y. K., Kwon, J. C., \& Choi, S. H. (2019). A Study on Technology Entrepreneurship Policy Focused on Innovative Growth. International Journal of Industrial Distribution \& Business, 10(2), 51-64.

Zardkoohi, A., \& Fraser, D. R. (1998). Geographical Deregulation and Competition in U.S. Banking Markets, Financial Review, $33(2), 85-98$. 